\title{
Effect of Selected Antibiotics and Other Inhibitors on Competence Development in Haemophilus influenzae
}

\author{
By J. M. RANHAND* AND H. C. LICHSTEIN \\ Department of Microbiology, The University of Cincinnati, \\ College of Medicine, Cincinnati, Ohio 45219
}

(Accepted for publication 23 August 1968)

SUMMARY

The effect of streptomycin, penicillin, polymyxin, chloramphenicol, novobiocin, erythromycin, D-cycloserine, 8-azaguanine, and 6-azauracil on competence development in Haemophilus influenzae was studied.

D-cycloserine and 6-azauracil had no inhibitory effects on either competence development or cell viability in concentrations that were inhibitory to growth. Penicillin and polymyxin reduced cell viability and competence development proportionately thereby maintaining a high percentage of transformation in the treated cultures. Chloramphenicol, novobiocin, 8azaguanine, erythromycin, and streptomycin inhibited markedly competence development with little or no effect on cell viability.

\section{INTRODUCTION}

The term 'competence' describes a specific physiological state attained by certain bacterial populations (Marmur, Falkow \& Mandel, 1963) that permits them to react with deoxyribonucleic acid (DNA), and this reaction between competent cells and DNA may result in a permanent genetic change or transformation.

In Haemophilus influenzae populations the attainment of the competent state has been shown to be dependent on protein synthesis since chloramphenicol prevented its development (Goodgal, 1958; Stuy, 1962; Leidy, Jaffee \& Alexander, 1962). The results presented here substantiate and extend these observations to other inhibitors of protein biosynthesis, namely, 8-azaguanine, novobiocin, erythromycin, and streptomycin.

The inhibition of competence development and transformation by sodium metaperiodate has been reported previously (Ranhand \& Lichstein, I966).

\section{METHODS}

Organism and cultural conditions. The organism used was Haemophilus influenzae strain RD described by Goodgal \& Herriott (I96I). The trypticase growth (phase-I) medium and cultural conditions employed have been described previously (Ranhand \& Lichstein, 1966; Ranhand \& Herriott, 1966).

Competence development and transformation. Competence was developed in the medium described by Spencer \& Herriott (1965) modified with $0.05 \%$ acid hydrolysed

* Present address: Laboratory of Microbiology, The National Institute of Allergy and Infectious Diseases, Bethesda, Maryland 200I4. 
casein (Ranhand \& Lichstein, 1966). Transformation to streptomycin resistance was determined by standard procedures (Ranhand \& Lichstein, 1966).

Transforming deoxyribonucleic acid (DNA). Transforming DNA was prepared according to the method of Goodgal \& Herriott (196I) from $H$. influenzae organisms that were resistant to about $2 \mathrm{mg}$. streptomycin per $\mathrm{ml}$.

Antibiotics and other inhibitors. The antibiotics and inhibitors used were as follows: streptomycin sulphate, sodium penicillin G, polymyxin B sulphate, D-cycloserine, chloramphenicol, sodium novobiocin, erythromycin gluceptate, 8-azaguanine, and 6-azauracil.

D-cycloserine was prepared in phosphate buffer, pH 8 (Curtiss, Berg \& Charamella, 1965). Chloramphenicol was dissolved in $40 \%$ ethanol at $2 \mathrm{mg}$. per $\mathrm{ml}$. and diluted appropriately with distilled water. 8-Azaguanine was dissolved in $0.04 \mathrm{M}-\mathrm{NaOH}$ at $2 \mathrm{mg} . / \mathrm{ml}$. and diluted appropriately in phosphate buffer, $\mathrm{pH} 6.7$. All other stock solutions were prepared in distilled water. All solutions were stored at $5-7^{\circ}$ and were used within I week after preparation.

Inhibition of competence development. Haemophilus influenzae cells were grown in the trypticase medium and diluted into the competence development medium with or without inhibitor. The cells were shaken at $37^{\circ}$ for $90 \mathrm{~min}$., at which time transforming DNA was added for $30 \mathrm{~min}$. At the end of the $30 \mathrm{~min}$. period the cells were diluted and plated according to standard procedures (Ranhand \& Lichstein, 1966).

\section{RESULTS AND DISCUSSION}

Effect of D-cycloserine, 6-azauracil, penicillin, and polymyxin on competence development

Since competence most likely involves the cell surface (Tomasz \& Beiser, 1965), agents that affect cell-wall biosynthesis and membrane integrity were tested for their ability in preventing competence development (Table I).

$\mathrm{D}$-Cycloserine, an inhibitor of D-alanyl-D-alanine synthetase and DL-alanine racemase (Strominger, Threnn \& Scott, 1959), and 6-azauracil, a potential inhibitor of cell-wall biosynthesis (Otsuji \& Takagi, 1959) had little or no influence on either viability or competence development yet both inhibited growth at concentrations greater than 5 and $13 \mu \mathrm{g}$. per $\mathrm{ml}$, respectively. These results suggest that biochemical processes in Haemophilus influenzae that lead to the competent state require neither D-alanyl-Dalanine synthetase, nor DL-alanine racemase, nor both, nor reactions that require pyrimidine nucleotides as biosynthetic carrier molecules (Strominger \& Smith, 1959). However, since these agents were added to organisms during the competence development period (phase-2), the negative results obtained here do not preclude their function during growth (phase-I).

Penicillin, an inhibitor of cell wall biosynthesis (Strominger, Kazuo, Matsuhashi \& Tipper, 1967), and polymyxin, a membrane destroying agent (Newton, 1956), inhibited both viability and competence development equally (Table I). Since organisms in competent cultures are at least $75 \%$ competent (Goodgal \& Herriott, 196I) or comprise a lower but constant percentage of the population (Thomas, 1955) this dual inactivation implies that both competent and non-competent organisms are affected to the same extent. Since sublethal concentrations of penicillin and polymyxin did not influence competence development, their direct effect on the process, if any, could 
not be evaluated. In these experiments, no attempt was made to protect potential spheroplasts from lysis.

The killing of both transformable and non-transformable $H$. influenzae in the competent population by penicillin differs from the result obtained by Nester (1964) with competent Bacillus subtilis populations. In this latter case, only the non-competent population appeared to be killed.

Table I. Effect of D-cycloserine, 6-azauracil, penicillin $G$, and polymyxin $B$ on competence development

\begin{tabular}{|c|c|c|c|c|c|}
\hline \multirow{2}{*}{$\begin{array}{l}\text { Inhibitor } \\
(\mu \mathrm{g} . / \mathrm{ml} .)\end{array}$} & \multirow{2}{*}{$\begin{array}{c}\text { Transformations } \\
\text { per ml. (T) } \\
\left(\times 10^{-7}\right)\end{array}$} & \multirow{2}{*}{$\begin{array}{l}\text { Viable cells (v.c.) } \\
\text { per ml. }\left(\times 10^{-9}\right)\end{array}$} & \multicolumn{2}{|c|}{ Survival (\%) } & \multirow{2}{*}{$\begin{array}{l}\text { Transformation } \\
\text { frequency }(\%)^{*}\end{array}$} \\
\hline & & & $\mathrm{T} / \mathrm{ml}$ & V.C./ml. & \\
\hline \multicolumn{6}{|c|}{ D-cycloserine } \\
\hline 0 & $2 \cdot I$ & $I \cdot 7$ & $(100)$ & $(100)$ & $I \cdot 2$ \\
\hline 5 & $1 \cdot 9$ & $1 \cdot 8$ & $9 \mathrm{I}$ & 106 & $I \cdot I$ \\
\hline 10 & $3 \cdot 2$ & $1 \cdot 5$ & 152 & 88 & $2 \cdot I$ \\
\hline 15 & $2 \cdot 2$ & $1 \cdot 7$ & 105 & 100 & $1 \cdot 3$ \\
\hline 20 & $4 \cdot 3$ & $2 \cdot 0$ & 205 & 118 & $2 \cdot I$ \\
\hline 25 & $2 \cdot 3$ & $I \cdot 8$ & I 10 & 106 & $1 \cdot 3$ \\
\hline \multicolumn{6}{|c|}{ 6-Azauracil } \\
\hline 0 & $4 \cdot 6$ & $x \cdot 7$ & $(100)$ & $(100)$ & $2 \cdot 7$ \\
\hline 12.5 & $4 \cdot 6$ & $1 \cdot 4$ & 100 & 82 & $3 \cdot 1$ \\
\hline 25 & 3.5 & $\mathbf{I} \cdot \mathbf{I}$ & 76 & 65 & $3 \cdot 2$ \\
\hline 50 & 2.6 & $1 \cdot 0$ & 54 & 59 & $2 \cdot 6$ \\
\hline 75 & $3 \cdot 0$ & $I \cdot 4$ & 65 & 82 & $2 \cdot 2$ \\
\hline 100 & $2 \cdot 8$ & $1 \cdot 4$ & $6 I$ & 82 & $2 \cdot 0$ \\
\hline \multicolumn{6}{|c|}{ Penicillin G } \\
\hline 0 & $I \cdot 8$ & $2 \cdot 4$ & $(100)$ & $(100)$ & 0.75 \\
\hline 0.1 & $I \cdot 6$ & $1 \cdot 7$ & 89 & 71 & 0.94 \\
\hline 0.2 & 0.6 & 0.8 & 33 & 33 & 0.75 \\
\hline 0.4 & 0.8 & 0.8 & 45 & 33 & $1 \cdot 00$ \\
\hline 0.6 & 0.4 & 0.8 & 22 & 33 & 0.50 \\
\hline \multicolumn{6}{|c|}{ Polymyxin B } \\
\hline 0 & $3 \cdot 1$ & $\mathbf{I} \cdot 9$ & $(100)$ & $(100)$ & $\mathbf{I} \cdot 7$ \\
\hline 0.5 & $3 \cdot 4$ & $1 \cdot 6$ & I IO & 84 & $2 \cdot 2$ \\
\hline $1 \cdot 0$ & $2 \cdot 6$ & $1 \cdot 4$ & 84 & 75 & $1 \cdot 9$ \\
\hline $1 \cdot 5$ & $1 \cdot 3$ & 0.6 & 42 & 32 & $2 \cdot I$ \\
\hline $2 \cdot 0$ & $I \cdot I$ & 0.5 & 36 & 24 & 2.4 \\
\hline $2 \cdot 5$ & 0.5 & $0 \cdot 2$ & 16 & 10 & $2 \cdot 6$ \\
\hline $3 \cdot 0$ & 0.06 & 0.05 & 2 & 3 & $I \cdot 2$ \\
\hline
\end{tabular}

* Transformation frequency equals the number of transformations per ml. $\times 100$ divided by the number of viable cells per $\mathrm{ml}$.

\section{Effect of chloramphenicol and 8-azaguanine on competence development}

The sensitivity of competence development to chloramphenicol is shown in Fig. I. At chloramphenicol concentrations that reduced the number of competent organisms to about $10 \%$ of control values $(0.7 \mu \mathrm{g} . / \mathrm{ml}$.), about $85 \%$ of the organisms remained viable; at concentrations where competence was reduced to less than $\mathrm{I} \%$ of the control values ( $1 \cdot 0 \mu \mathrm{g} . / \mathrm{ml}$.), about $50 \%$ of the organisms remained viable. These data show that competence development is more sensitive to the action of chloramphenicol than is viability. 
When 8-azaguanine was used to inhibit competence development (Fig. 2) there was no apparent loss in viability at concentrations that reduced the level of competence to about $5 \%$ of control values $(3 \cdot 0 \mu \mathrm{g} . / \mathrm{ml}$.).

\section{Effect of erythromycin, streptomycin, and novobiocin on competence development}

Since chloramphenicol and 8-azaguanine inhibited competence development it was also of interest to see if other inhibitors of protein biosynthesis acted in a similar fashion. Therefore, the effects of erythromycin, novobiocin, and streptomycin were examined.

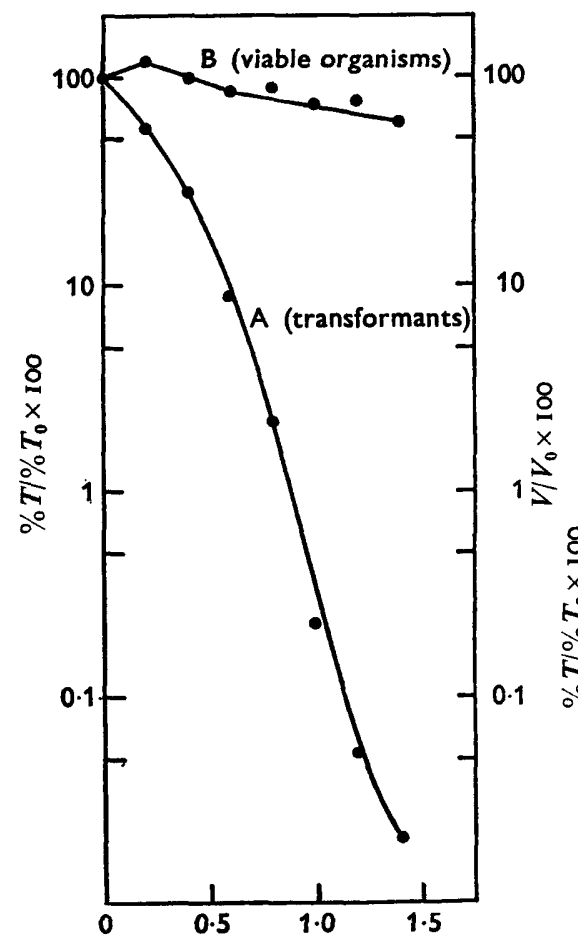

Chloramphenicol concentration $(\mu \mathrm{g} . / \mathrm{ml}$.)

Fig. I

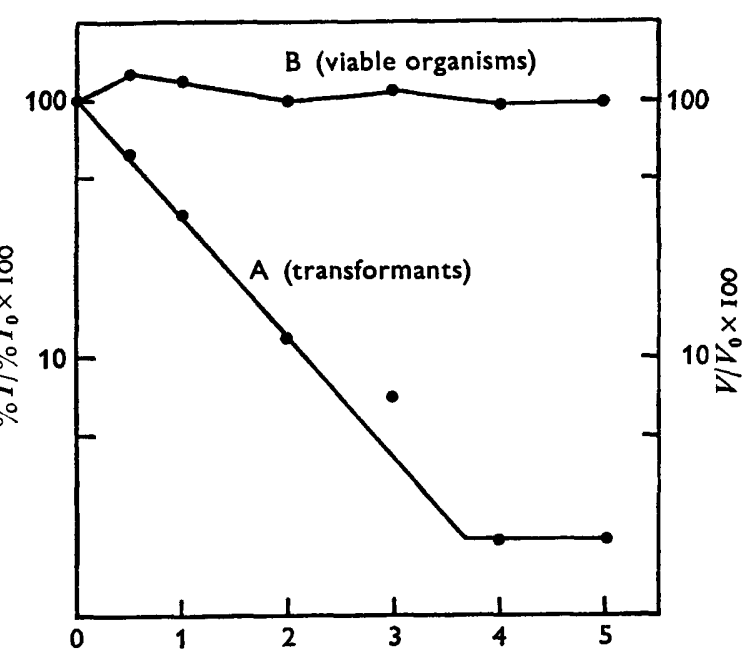

8-Azaguanine concentration ( $\mu \mathrm{g} . / \mathrm{ml}$.)

Fig. 2

Fig. I. Inhibition of competence development by chloramphenicol. Curve A (transformants) $=$ percentage transformation of treated cultures $(T)$ divided by percentage transformation of untreated control $\left(T_{0}\right) \times 100$. Curve B (viable organisms) = viable organisms per $\mathrm{ml}$. of treated cultures $(V)$ divided by viable cells per ml. of untreated control $\left(V_{0}\right) \times 100 . T_{0}=$ $4.3 \times 10^{7}$ per ml.; $V_{0}=1.6 \times 10^{9}$ per $\mathrm{ml}$.

Fig. 2. Inhibition of competence development by 8-azaguanine. Curves A (transformants) and B (viable organisms) have the same notation as described in the legend to Fig. I. $T_{0}=2 \cdot 6 \times$ $10^{7}$ per $\mathrm{ml}$.; $V_{0}=\mathrm{I} \cdot 6 \times 10^{9}$ per $\mathrm{ml}$.

Erythromycin inhibited competence development in a very complex manner yet had no effect on viability at concentrations that reduced transformation to $\mathrm{I} \%$ of control values (I.0 $\mu \mathrm{g} . / \mathrm{ml}$.) (Fig. 3). Novobiocin ( 0.1 to $0.6 \mu \mathrm{g} . / \mathrm{ml}$.) and streptomycin (I to $4 \mu \mathrm{g} . / \mathrm{ml}$.) (Figs. 4,5 ) likewise inactivated competence development in a complex 
manner, but viability was also reduced to about $50 \%$ of the control values. The complexity of these inactivation curves may reflect the modes of action of these agents (Davis \& Feingold, I962; Taubman, Jones, Young \& Corcoran, 1966; Brock, 1966; Wishnow, Strominger, Birge \& Threnn, 1965) or heterogeneity in the populations

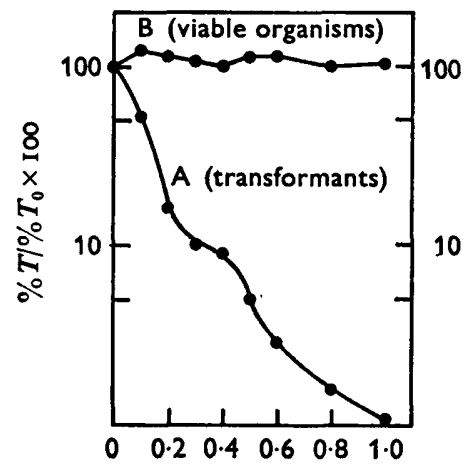

Erythromycin concentration ( $\mu \mathrm{g} . / \mathrm{ml}$.

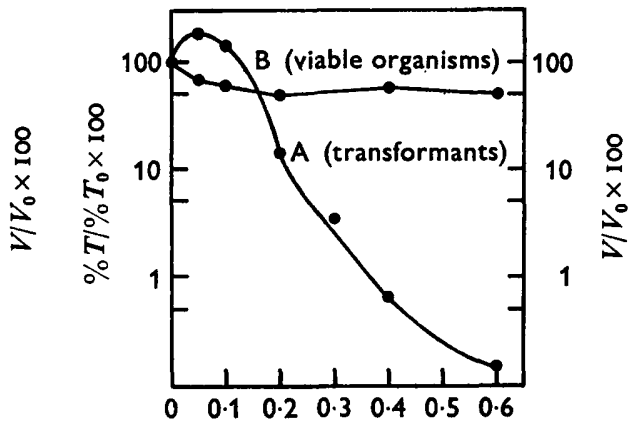

Novobiocin concentration ( $\mu \mathrm{g} . / \mathrm{ml}$.)

Fig. 3

Fig. 4

Fig. 3. Inhibition of competence development by erythromycin. Curves A(transformants) and $B$ (viable organisms) have the same notation as described in the legend to Fig. $1 . T_{0}=4 \cdot 6 \times$ $10^{2}$ per ml.; $V_{0}=1.4 \times 10^{\circ}$ per $\mathrm{ml}$.

Fig. 4. Inhibition of competence development by novobiocin. Curves A (transformants) and B (viable organisms) have the same notation as described in the legend to Fig. $1 . T_{0}=$ $3.1 \times 10^{7}$ per ml.; $V_{0}=1 \cdot 9 \times 10^{9}$ per $\mathrm{ml}$.

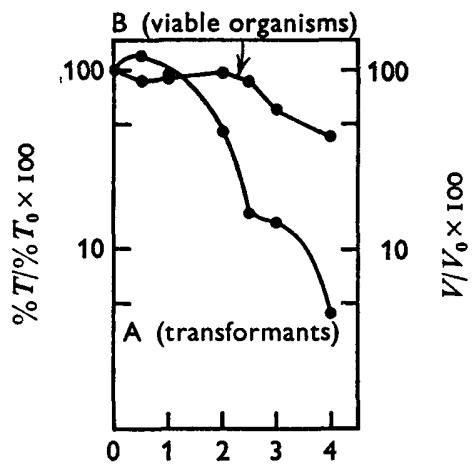

Streptomycin concentration ( $\mu \mathrm{g} . / \mathrm{ml}$.

Fig. 5

Fig. 5. Inhibition of competence development by streptomycin. Curves A (transformants) and $\mathbf{B}$ (viable organisms) have the same notation as described in the legend to Fig. I. $T_{0}=4.3 \times 10^{7}$ per ml.; $V_{0}=2.0 \times 10^{9}$ per ml.

tested. Moreover, since the effect of these antibiotics was similar, and since streptomycin can precipitate DNA (Cohen, 1947), it was thought that these compounds were inactivating the transforming DNA. However, the results given in Table 2 show that this was not the case; these antibiotics were acting on some cellular processes. 
The data presented here, at least for the prevention of competence development produced by chloramphenicol, implies that the attainment of the competent state by Haemophilus influenzae organisms may be the result of the induction of an enzyme or protein (Sypherd, Strauss \& Treffers, 1962; Weber \& DeMoss, 1966). It is believed that the function of this protein is to activate or modify pre-existing DNA binding sites that are produced by the metabolism of inosine and lactate during phase-I (Ranhand \& Lichstein, 1966).

Table 2. Effect of various antibiotics on transforming $D N A^{*}$

$\begin{array}{lccc}\begin{array}{l}\text { Antibiotic }(\mu \mathrm{g} / \mathrm{ml} .) \\ \text { None }\end{array} & \begin{array}{c}\text { Transformations } \\ \text { per ml. }\left(\times 10^{-8}\right)\end{array} & \begin{array}{c}\text { Viable cells } \\ \text { per ml. }\left(\times 10^{-8}\right)\end{array} & \begin{array}{c}\text { Transformation } \\ \text { frequency }(\%) \dagger\end{array} \\ \begin{array}{l}\text { Erythromycin } \\ 0.25\end{array} & 3.6 & 2.5 & 0.14 \\ \quad 0.6 & 3.7 & 2.7 & 0.14 \\ \text { Streptomycin } & 3.4 & 2.2 & 0.16 \\ 3 & & & 0.14 \\ 6 & 3.4 & 2.4 & 0.16 \\ \text { Novobiocin } & 3.7 & 2.4 & \\ 0.3 & & & 0.15 \\ 0.6 & 3.6 & 2.4 & 0.14\end{array}$

* $H$. influenzae organisms were grown in the trypticase medium and made competent as already described (Ranhand \& Lichstein, I966). Transforming DNA (I.I $\mu \mathrm{g} . / \mathrm{ml}$.$) was pre-incubated in the$ competence development medium with or without the antibiotics as indicated above for $30 \mathrm{~min}$. at $37^{\circ}$ prior to its addition to competent cells. The final DNA concentration added to competent organisms was $0.06 \mu \mathrm{g} . / \mathrm{ml}$.

$\dagger$ Transformation frequency equals the number of transformed organisms per $\mathrm{ml} . \times 100$ divided by the number of viable organisms per $\mathrm{ml}$.

This work was supported in part by grants nos. GB 2595 and GB6793 from the National Science Foundation and by a contract with the Office of Naval Research (NR-103-555). One of us (J.M.R.) was a trainee supported by Public Health Service grant 5T I-GM I 255 from the National Institutes of Health.

This paper was taken in part from a dissertation submitted by J.M.R. in partial fulfilment of the requirements for the $\mathrm{Ph} . \mathrm{D}$. degree at the University of Cincinnati.

\section{REFERENCES}

Brock, T. D. (1966). Streptomycin. Symp. Soc. gen. Microbiol. 16, I3I.

CoHen, S. S. (1947). Streptomycin and deoxyribonuclease in the study of variations in the properties of a bacterial virus. J. biol. Chem. x68, $5 \mathrm{II}$.

Curtiss, R., II, Berg, C. M. \& Charamella, L. J. (1965). Mutant isolation by D-cycloserine enrichment cycling technique. Bact. Proc. p. I7.

Davis, B. D. \& FeIngold, D.S. (1962). Antimicrobial agents: Mechanism of action and use in metabolic studies. In The Bacteria. Ed. by I. C. Gunsalus and R. Y. Stanier. Vol. 4, p. 343. New York: Academic Press.

Goodgal, S. H. (1958). Expression and segregation in Hemophilus influenzae transformations. Proc. roth int. Congr. Genet. 11, 100.

GoOdGal, S. H. \& HerRiotr, R. M. (196I). Studies on transformations of Hemophilus influenzae. I. Competence. J. gen. Physiol. 44, 1201.

LeIDY, G., JAFFe, I. \& AleXANDER, H. E. (I962). Emergence of competence (for transformation) of three Hemophilus species in a chemically defined environment. Proc. Soc. exp. Biol. Med. Irr, 725 . 
Marmur, J., Falkow, S. \& Mandel, M. (1963). New approaches to bacterial taxonomy. A. rev. Microbiol. I7, 329.

Nester, E. W. (1964). Penicillin resistance of competent cells in deoxyribonucleic acid transformation of Bacillus subtilis. J. Bact. 87, 867.

Newton, B. A. (1956). Properties and mode of action of the polymyxins. Bact. Rev. $20,14$.

OTSUI, N. \& TAKAGI, Y. (1959). Effect of 6-azuracil on cells and subcellular preparations of Escherichia coli. J. Biochem., Tokyo 46, 791.

RANHAND, J. M. \& HERRIOTT, R. M. (1966). Inosine and lactate: Factors critical during growth for development of competence in Haemophilus influenzae. Biochem. biophys. Res. Commun. 22, 591.

Ranhand, J. M. \& Lichstein, H. C. (1966). Periodate inhibition of transformation and competence development in Haemophilus influenzae. J. Bact. 92, 956.

SPENCER, H. T. \& HerRIOTT, R. M. (1965). Development of competence of Haemophilus influenzae. J. Bact. 90, $91 \mathrm{I}$.

STrominger, J. L. \& SMrTH, M. S. (1959). Uridine diphosphoacetyl-glucosamine pyrophosphorylase. J. biol. Chem. 234, 1822.

Strominger, J. L., THRenN, R. H. \& Scotr, S. S. (1959). Oxymycin, a competitive antagonist of the incorporation of D-alanine into a uridine nucleotide in Staphylococcus aureus. J. Am. chem. Soc. 8r, 3803 .

Strominger, J. L., Kazuo, I., Matsuhashi, M. \& TIPPer, D. J. (1967). Peptidoglycan transpeptidase and D-alanine carboxypeptidase: Penicillin-sensitive enzymatic reactions. Fedn. Proc. Fedn. Am. Socs. exp. Biol. $26,9$.

STUY, J. H. (1962). Transformability of Haemophilus influenzae. J. gen. Microbiol. $29,537$.

SYPherd, P. S., STrauss, N. \& Treffers, H. P. (1962). The preferential inhibition by chloramphenicol of induced enzyme synthesis. Biochem. biophys. Res. Commun. 7, 477.

TAUbman, S. B., Jones, N. R., Young, F. E. \& Corcoran, J. W. (1966). Sensitivity and resistance to erythromycin in Bacillus subtilis $\mathrm{I} 68$ : the ribosomal binding of erythromycin and chloramphenicol. Biochem. biophys. Acta 123, 438.

Thомas, R. (1955). Recherches sur la cinétique des transformations bactériennes. Biochem. biophys. Acta $\mathbf{1 8}, 467$.

TOMASZ, A. \& BeISER, S. M. (1965). Relationship between the competence antigen and the competenceactivator substance in pneumococci. J. Bact. 90, 1226.

Weber, M. J. \& DeMoss, J. A. (1966). The inhibition by chloramphenicol of nascent protein formation in E. coli. Proc. natn. Acad. Sci. U.S.A. 55, 1224.

Wishnow, R. M., Strominger, J. L., Birge, C. H. \& THrenn, R. H. (1965). Biochemical effects of novobiocin on Staphylococcus aureus. J. Bact. 89, I I 17. 